\title{
Fungal infection control by garlic extracts (Allium sativum L.) and modulation of peritoneal macrophages activity in murine model of sporotrichosis
}

\author{
J. P. Burian ${ }^{a *}$, L. V. S. Sacramento ${ }^{a}$ and I. Z. Carlos $^{b}$

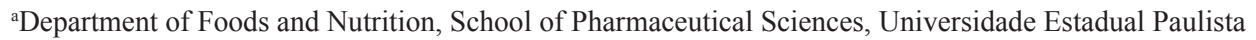 \\ "Júlio de Mesquita Filho" - UNESP, Rodovia Araraquara-Jaú, Km 1, CEP 14801-902, Araraquara, SP, Brazil

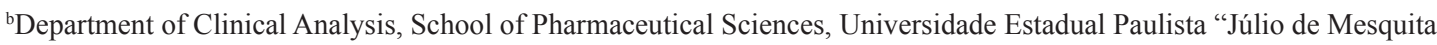 \\ Filho" - UNESP, Rodovia Araraquara-Jaú, Km 1, CEP 14801-902, Araraquara, SP, Brazil \\ *e-mail: joaopauloburian@gmail.com
}

Received: March 22, 2016 - Accepted: July 10, 2016 - Distributed: November 31, 2017

(With 5 figures)

\begin{abstract}
Garlic (Allium sativum L.) is grown all over the world as seasoning and medicinal vegetable since 3,000 BC. Allicin is the main component of garlic, being attributed to it the most of its biological activities, such as bactericidal, antifungal and antiviral actions. However, other compounds of garlic present antioxidant, hypocholesterolemic, vasodilator activities, protective action against different types of cancer, and immunomodulatory. Fungal infections are important causes of morbidity and mortality in people mainly in immunosuppressed ones. Sporothrix schenckii, the causing agent of Sporotrichosis (most common subcutaneous mycosis in Latin America), is dimorphic fungus, of saprophytic life in soil or plants, infecting people and animals mainly through skin injuries and bruises. The main of this work was to evaluate the influence of garlic consuming on immune modulation of healthy and infected Swiss mice in induced way by $S$. schenckii, since these animals functioning of peritoneal macrophages as well as the nitric oxide and cytokines' production (IL-1 $\beta$, IL-10 and IL-12) and to evaluate the antifungal potential of garlic with $S$. schenckii through minimum inhibitory concentration test and colony-forming units. The results showed that garlic offers antifungal potential with S. schenckii. The oral taking of garlic extracts influences the releasing of cytokines by macrophages, regular consuming shows anti-inflammatory effect, and its acute use may take to an inflammatory response. Mice that consumed garlic responded more effectively to fight against the infection.
\end{abstract}

Keywords: garlic, macrophage, Sporothrix schenckii, sporotrichosis, interleukin.

\section{Controle da infecção fúngica pelos extratos de alho (Allium sativum L.) e modulação da atividade de macrófagos peritoneais em modelo murino de esporotricose}

\begin{abstract}
Resumo
O alho (Allium sativum L.) é cultivado em todo o mundo como hortaliça condimentar e medicinal desde 3.000 a. C. A alicina é o principal componente do alho, sendo atribuída a ela a maior parte das suas atividades biológicas, dentre elas as ações bactericida, antifúngica e antiviral. Porém, outros compostos do alho apresentam atividade antioxidante, hipocolesterolemiante, vasodilatadora, ação protetora contra diversos tipos de câncer e imunomoduladora. As infecções por fungos são causas importantes de morbidade e mortalidade no homem principalmente em indivíduos imunossuprimidos. O Sporothrix schenckii, agente causal da esporotricose (micose subcutânea mais comum na América Latina), é fungo dimórfico, de vida saprofítica no solo ou em vegetais, infectando homens e os animais principalmente através de lesões e arranhões na pele. O objetivo desse trabalho foi avaliar a influência do consumo de alho na imunomodulação de camundongos Swiss saudáveis e infectados de forma induzida por S. schenckii, a partir do estado funcional dos macrófagos peritoneais desses animais quanto à produção de óxido nítrico e das citocinas (IL-1 $\beta$, IL-10 e IL-12) e avaliar o potencial antifúngico do alho frente ao $S$. schenckii por meio de teste de concentração inibitória mínima e unidades formadoras de colônia. Os resultados demonstraram que o alho apresenta potencial antifúngico frente S. schenckii. A administração oral de extratos de alho influencia a liberação de citocinas por macrófagos, o consumo regular apresenta efeito anti-inflamatório, e seu uso agudo pode gerar uma resposta inflamatória. Camundongos que consumiram alho responderam de forma mais efetiva no combate da infecção.
\end{abstract}

Palavras-chave: alho, macrófago, Sporothrix schenckii, esporotricose, interleucina. 


\section{Introduction}

Garlic (Allium sativum L.) is grown all over the world as seasoning and medicinal vegetable since 3,000 BC by the Sumerians and East Indians (García Gómez and Sánchez-Muniz, 2000; Abreu-Matos, 2000; Holub et al., 2002). Its chemical structure is very complex and perhaps is made as a self-protection way against micro-organisms and other threats mainly present in soil (Amagase et al., 2001).

Among its ingredients with biological activity, perhaps the most important are the organosulfur compounds that are present in 11-35 mg per gram of fresh garlic. Garlic contains three times more sulfur than onion, in addition to arginine, oligosaccharides, flavonoids and selenium (Holub et al., 2002; Milner and Donato, 2010). Its taste and burning characteristics are because of the hydrolysis of S-alk compounds (en) yl cysteine sulphoxides (ACSOs) by alliinase enzyme (Randle and Lancaster, 2002). The alliin (S-alilcisteína S-oxide) is the main organsulfur ingredient identified in intact garlic bulbs, as when they are cut or grinded, the alliin is changed to allicin by alliinase. The chemical changing of allicin by the heat it yields other sulfur compounds such as ajoenos, vinilditiina and methyl allyl trisulfide (Ankri and Mirelman, 1999).

Nutrition plays an important role in modulating the immune and inflammatory response, as the nutrients regulate cellular and humoral defensing systems, by the changing in the formation of mediators or by interfering with the transduction pathways of cellular signals, altering the balance between cytokines, and lessen depletion of tissue nutrients (Parham, 2011).

Several cytokines produced by leukocytes are called interleukins. Interleukin-1 (IL-1), for instance, mediates inflammation and is produced mainly by activated macrophages. Its effects include stimulating the production of chemokines, increasing production of neutrophils by bone marrow, and increasing inflammatory activity. However, this process can be highly regulated by antagonist action such as interleukin-10 (IL-10) (Correa-Camacho et al., 2007; Parham, 2011; Trevor et al., 2014).

The IL-10 suppresses the activity of activated macrophages, T cells and Natural killer cells (NK), and also causes inhibition of interleukin 12 (IL-12) in macrophages, which is the main form of NK cells activation. The IL-12 stimulates production of IFN-y by NK cells and $\mathrm{T}$ lymphocytes, enhances cytotoxicity mediated by NK cells and stimulates differentiation of T cells. Although many other cells appear to secrete IL-12, only macrophages and dendritic cells yield the biologically active cytokine (Abbas et al., 2012; Oliveira et al., 2011).

Macrophages play a basic key role in defending the body system, by phagocytosis, bringing forth free radicals, mediation of inflammation process and secretion of diverse substances (Fischer et al., 2008). It belongs to the mononuclear phagocyte system, and are a part, along with NK cells, of the first line of defense against pathogens (Klimp et al., 2002). They are classified as M1 and M2, being M1 producer of the nitric oxide synthase enzyme, so it puts down L-arginine, yelding nitric oxide (NO), vasodilator that also modulates inflammatory or anti-inflammatory reactions, depending on cell type and stimulus (Alegranci, 2013; Cerqueira and Yoshida, 2002; Morihara et al., 2002).

Fungal infections are a significant cause of morbidity and mortality in humans. They are considered opportunistic as the etiologic agents cause mild illness or no illness in healthy people, but it may infect and cause serious diseases in immunosuppressed ones. A simple infection such as candidiasis may be severe and invasive, colonizing the esophagus, stomach and intestine in patients with immunodeficiency syndrome (Abbas et al., 2012; Coelho-Castelo et al., 2009; Janeway et al., 2000).

Phagocytes, mainly macrophages, respond against fungi and mycoses through the enzyme NO-induced and other mediators secreted to destroy these pathogens. The cytokines participation is essential once it increases the fungicide capacity of phagocytes, furthering the fungus destruction (Coelho-Castelo et al., 2009).

The Sporothrix schenckii, causal agent of sporotrichosis is dimorphic fungus, of saprophytic life in soil or plants occasionally infecting people and animals. In man, most of infections are caused by splinters, wood or wire injuries (Marques et al., 1993). The mycelial form saprophytic of fungus found in the environment grows at temperatures ranging from $25^{\circ} \mathrm{C}$ to $30^{\circ} \mathrm{C}$. The yeast form is found in vivo, at $37^{\circ} \mathrm{C}$, where it reproduces by budding (Alegranci, 2013).

The sporotrichosis injuries are usually limited to the skin, subcutaneous tissue, and nearby lymph vessels. Rarely it may spread to other organs or even be systemic, resulting from inhalation of spores. The infection can be classified as skin, cutaneous lymphatic, skin spread, mucosal and systemic (Barros et al., 2010). It is the most common subcutaneous mycosis in Latin America, and it has been seen in many countries, in animals and people, it is worth to say that in the 90's in the Rio de Janeiro State the disease reached epidemic proportions (Barros et al., 2010).

The aim of this study was to evaluate the influence of garlic (Allium sativum L.) consumption in immunomodulation of healthy and infected Swiss mice induced by S. schenckii.

\section{Methodology}

\subsection{Obtaining and administering of extracts}

Aquous and oily extracts were prepared using $32 \mathrm{~g}$ of garlic cloves (Allium sativum L.) peeled and crushed in $200 \mathrm{~mL}$ of distilled water or soybean oil, allowed it to rest for half an hour, and then it was cooled and filtered. The dose of the extracts $(0.1 \mathrm{~mL})$ used in the treatment corresponded to $400 \mathrm{mg} \mathrm{kg}^{-1}$ administered by gavage once daily for 15 days.

\subsection{Obtaining of peritoneal exudate cells}

Peritoneal exudate's cells (PECs) of Swiis mice, male, adult, healthy or infected with fungus $S$. schenckii were collected after the animals were previously submitted to $3.0 \mathrm{~mL}$ of sodium thioglycollate $3 \%$ by intraperitoneal 
inoculation three days before they were euthanized in a $\mathrm{CO}_{2}$ chamber. The animals had abdominal skin removed aseptically in a laminar flow cabinet and the peritoneum was exposed. It was inoculated $5 \mathrm{~mL}$ of cold PBS with pH 7.2 into the abdominal cavity. The resulting peritoneal fluid was collected and transferred into a conical sterile tube and centrifuged at $2500 \mathrm{rpm}$ for 5 minutes. The cell pellet was washed three times with $3 \mathrm{~mL}$ of PBS. The cell suspension was adjusted to final concentration of $5 \times 10^{6}$ cells to accomplish the proposed tests, and the plates with PECs were incubated for one hour in $\mathrm{CO}_{2}$ incubator at $37^{\circ} \mathrm{C}$ for the formation of the adherent cells layer pad, and after that the supernatant was discarded and the extracts and solutions corresponding the tests were added on cells.

\subsection{Determination of $N O$}

The NO was spectrophotometrically measured by the Griess Reaction (Green et al., 1982). The determination of the nitric oxide (NO) releasing was performed on floating (PECs) from infected and uninfected mice with S. schenckii fungus by the garlic extracts challenge $\left(1 \mathrm{mg} \mathrm{mL}^{-1}\right)$ and LPS control (positive control) or RPMI-1640-C (negative control). The control group did not receive garlic extract by gavage, however these groups of PECs were challenged with two different extracts (aqueous and oily).

\subsection{Determination of cytokines}

The IL-1 $\beta$, IL-10 and IL-12 cytokines in floating were quantified (PECs) obtained as challenged as described above. Quantitation was done by the ELISA enzyme immunoassay of capturing for each cytokine.

\subsection{Micro-organism, culture conditions and experimental infection}

It was used the 16345 strain of Sporothrix schenckii isolated from a pulmonary human infection of sporotrichosis (Baltimore, MD), courtesy of Reference Materials Laboratory of the Oswaldo Cruz Foundation. Currently, this isolate is kept in the Clinical Immunology Laboratory of the Department of Clinical Analysis of Pharmaceutical Sciences School of Araraquara - UNESP, in the mycelial stage in Sabouraud broth, at room temperature $\left( \pm 25^{\circ} \mathrm{C}\right)$. The yeasty form is obtained in BHI (Brain Heart Infusion, Difco) liquid at $37{ }^{\circ} \mathrm{C}$ under constant stirring of $150 \mathrm{rpm}$ during seven days. Thereafter, an aliquot containing 107 fungal units was transferred to a $250 \mathrm{~mL}$ Erlenmeyer containing $100 \mathrm{~mL}$ of BHI broth, and cultured for five days under the same conditions, in that it corresponds with the phase of logarithmic growth previously described by Ferreira et al. (2015). The animals were inoculated with $200 \mu \mathrm{L}$ of a suspension containing $10^{6}$ S. schenckii yeast in PBS or an equal volume of PBS alone by intraperitoneal administration.

\subsection{Determination of fungal load}

The evaluation of the systemic fungal load for infections monitoring was made considering a determination of colony forming units (CFU) in the spleen of the animals after they were removed. The CFU were counted after 3 days, and affirmed after 5 days of incubation at room temperature.

\subsection{Evaluation of antifungal capacity by microdilution}

Evaluation of antifungal activity was performed using the microdilution test according to Standard M27-A2 of National Committee for Clinical Laboratory Standards. The culture of $S$. schenckii was used by preparing an inoculum in sterile PBS. Serial dilutions were done in RPMI-1640 medium with MOPS, with the fungal suspension adjusted to a concentration of $2.5 \times 10^{3} \mathrm{CFU} \mathrm{mL} \mathrm{m}^{-1}$.

\subsection{Statistical analysis}

The results were expressed as mean \pm standard deviation and were submitted to Lilliefors test to verify the normality, the Levene test to verify the homoscedasticity, and variance analysis (ANOVA one way - Tukey post test). The significance rating assumed was $5 \%(\mathrm{p}<0.05)$.

\section{Results}

The cellular viability in the tests was kept above $90 \%$ by all stimulus, indicating that the analysis were not toxic to the cells. The nitric oxide (NO) production by PECs revealed that healthy animals of the AG have a significantly lower production $(\mathrm{p}<0.05)$ of $\mathrm{NO}$ compared to $\mathrm{OG}$ and CG. However, animals not previously exposed to extracts (CG), when stimulated by the extracts, show more NO production, compared to the negative control, what does not occurs in animals that receive the garlic extract orally (AG). This shows that the garlic immunomodulatory activity may be used in different ways, in that the response changes if it is ingested regularly or in acute way (Figure 1A).

The AG infected with the $S$. schenckii fungus, it had a significant increase $(\mathrm{p}<0.05)$ in the NO production by PECs challenged with aqueous extract compared to the negative control. This shows that the consumption of garlic may increase the production of NO, even in conditions that the production is already increased, as in this case by the induced infection (Figure 1B). The infection increased the NO production in all groups, this is shown in Figures 1C, 1D and 1E.

The IL-1 $\beta$ production in healthy animals from different groups were statistically different $(\mathrm{p}<0.01)$, and the group of animals that were treated with the extract has shown lower production of cytokine (Figure 2A). It was also different the production of this cytokine in healthy animals in the same group, comparing the extract stimulus with their respective controls (LPS and RPMI) $(* * * p<0.001)$, which did not happen with infected animals (Figure 2B). The IL-1 $\beta$ production in infected animals did not differed between the studied groups faced by the challenges with extracts, there was only a difference between the positive control, in that all were different among them, with higher production for the OG. Clearly, the garlic extracts have showed anti-inflammatory activity when administered in a chronic way (15 days), however, PECs of the animals that did not have previous contact with the extracts (CG), when challenged with the garlic extracts, it showed higher 
A

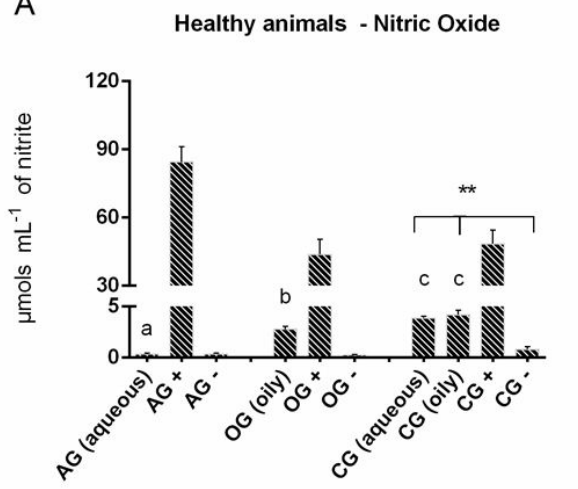

B

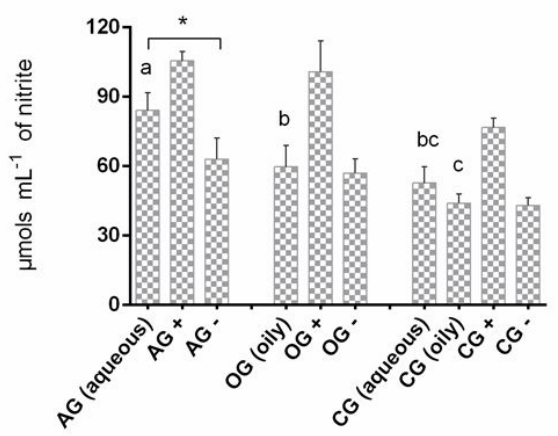

OG - Nitric Oxide
Infected animals - Nitric Oxide

$E$
CG - Nitric Oxide

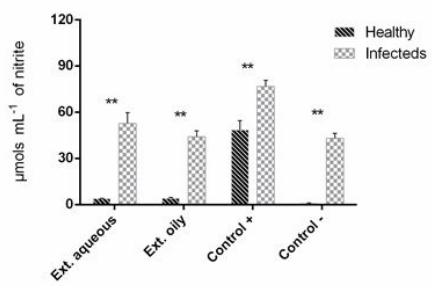

Figure 1. Production of NO in culture of peritoneal exudate cells of Swiss mice healthy and infected with S. schenckii fungus on the $10^{\text {th }}$ day after infection. AG (group that received aqueous extract), OG (group that received oily extract) and CG (group that received PBS) by gavage. Same letters does not show significantly statistical difference. Different letters are statistically different. ANOVA - Tukey's post test $(\mathrm{p}<0.05)$. Comparison between extract stimulus in A and B. Comparison between healthy and infected in $\mathrm{C}, \mathrm{D}$ and $\mathrm{E}(* \mathrm{p}<0.05 ; * * \mathrm{p}<0.01)$.

A

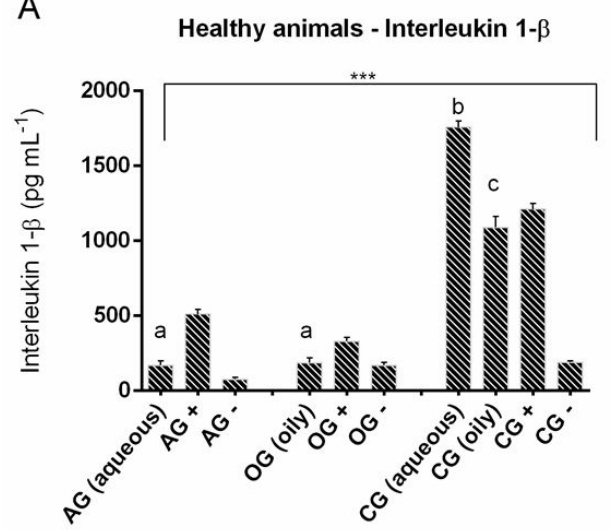

B
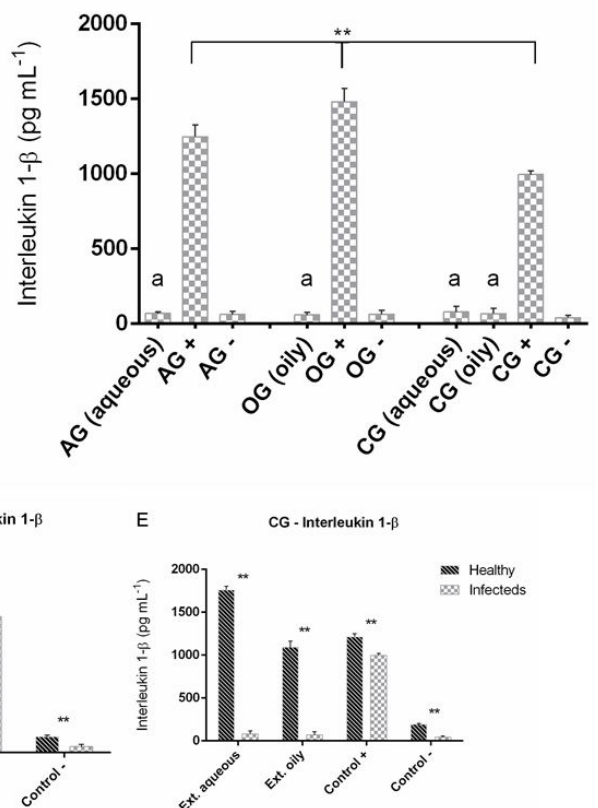

Figure 2. The IL-1 $\beta$ concentration released in PECs culture treated with sodium thioglycollate $3 \%$ of Swiss mice healthy and infected with $S$. schenckii fungus on the $10^{\text {th }}$ day after infection. AG (group that received aqueous extract), OG (group that received oily extract) and CG (group that received PBS) by gavage. Same letters does not show significantly statistical difference. Different letters show significant difference (ANOVA - Tukey's post-test $(\mathrm{p}<0.05)$ ). Comparison between extract stimulus in A and B. Comparison between healthy and infected in $\mathrm{C}, \mathrm{D}$ and $\mathrm{E}(* * \mathrm{p}<0.01 ; * * * \mathrm{p}<0.001)$. 
values to LPS challenge (positive control), indicating that the acute use of garlic may be a potent stimulator of IL- $1 \beta$ production, especially in healthy ones.

Among the healthy animals, those that were given garlic extract had IL-10 production increased (Figure 3A), compared to the group that did not received the extract orally (CG). In AG and OG treatments, the LPS challenge, $\mathrm{NC}$ and extract corresponding were significantly different.

The production of IL- 12 by healthy animals that received garlic extract orally (AG and $\mathrm{OG}$ ) and were stimulated by the extracts was lower compared to those that did not received (CG), however in infected animals the response was unlike, animals from AG and OG stimulated by their extracts show a higher production when compared to the animals of the control group in that it was equally stimulated (Figures 4A and 4B). PECs of CG when challenged with the extracts showed values of IL-12 production above the positive control (Figure 4A).

\subsection{Determination of fungal load (CFU)}

The groups treated with garlic showed a higher ability to control the infection, as can be seen in Figure 5.

\subsection{Evaluation of antifungal capacity by microdilution}

The Table 1 shows the antifungal activity of the extracts at its minimum concentration.

A Healthy animals - Interleukin 10

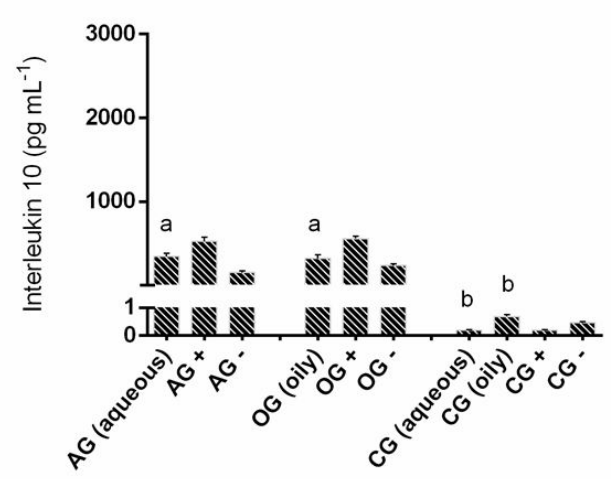

C

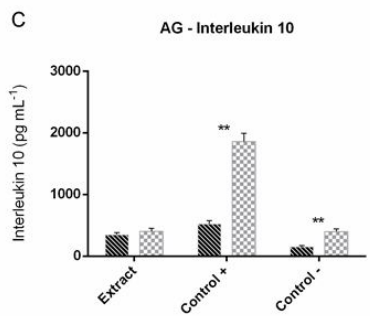

D

OG - Interleukin 10

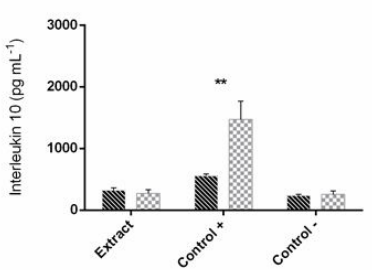

\section{Discussion}

It is known that in natura garlic or in the form of extracts reduces fungal growth, cause damage to the membrane and inhibit the synthesis of lipids, proteins and nucleic acids (Harris et al., 2001; Bayan et al., 2014). Studies with aged garlic extract have not shown antifungal activity in vitro, however, when orally administered to infected mice, the number of bodies that were seen was reduced by $80 \%$ (Bayan et al., 2014), which may be explained by the complex interaction of the garlic compounds and immune system cells.

In this research, the $10^{\text {th }}$ day post-infection, active washout of fungus, infected animals that were treated with garlic extracts showed much lower fungal load compared to untreated animals, that is, it caused a more effective response in infection control demonstrating effectiveness

Table 1. Determination of Minimum Inhibitory Concentration (MIC).

\begin{tabular}{cc}
\hline Extract & MIC $\left(\mathbf{m g ~ m L}^{-1}\right)$ \\
\hline Aquous & 0.62 \\
Oily & 2.5 \\
\hline
\end{tabular}

MIC of garlic extracts (aquous e oily). There was no inhibition in positive control (only fungus) and no increase in negative control (only half).
B
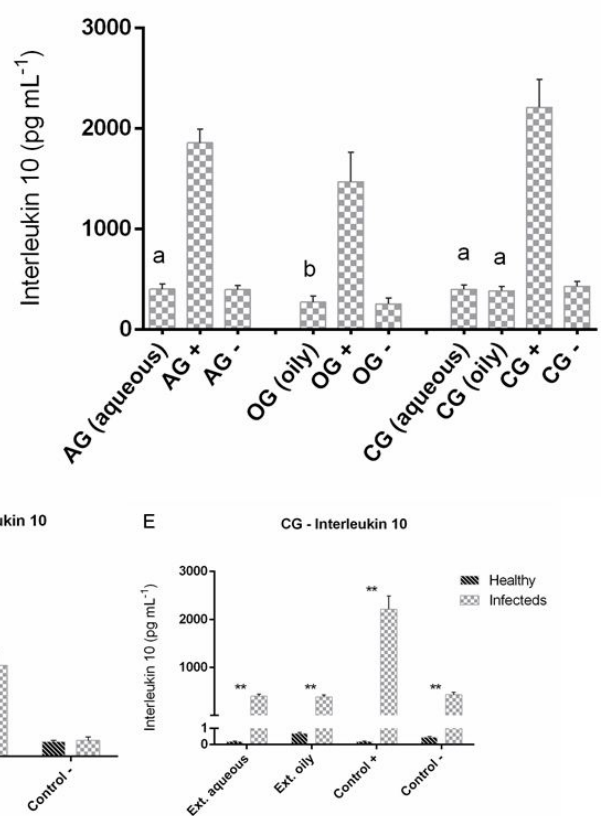

Figure 3. The IL-10 concentration released in PECs culture treated with $3 \%$ sodium thioglycolate of Swiss mice healthy and infected with $S$. schenckii fungus on the $10^{\text {th }}$ day after infection. AG (group that received aqueous extract), OG (group that received Oily extract) and CG (group that received PBS) by gavage. The animals macrophages were cultured in aqueous extract $\left(1 \mathrm{mg} \mathrm{mL}^{-1}\right)$, oily extract $\left(1 \mathrm{mg} \mathrm{mL}^{-1}\right)$, LPS (Control +) and only RPMI-1640-C (Control -). Same letters does not show significant statistical difference. Different letters show significant difference (ANOVA - Tukey post-test $(p<0.05)$ ). Comparison between extract stimulus in A and B. Comparison between healthy and infected in C, D and $\mathrm{E}(* * \mathrm{p}<0.01)$. 

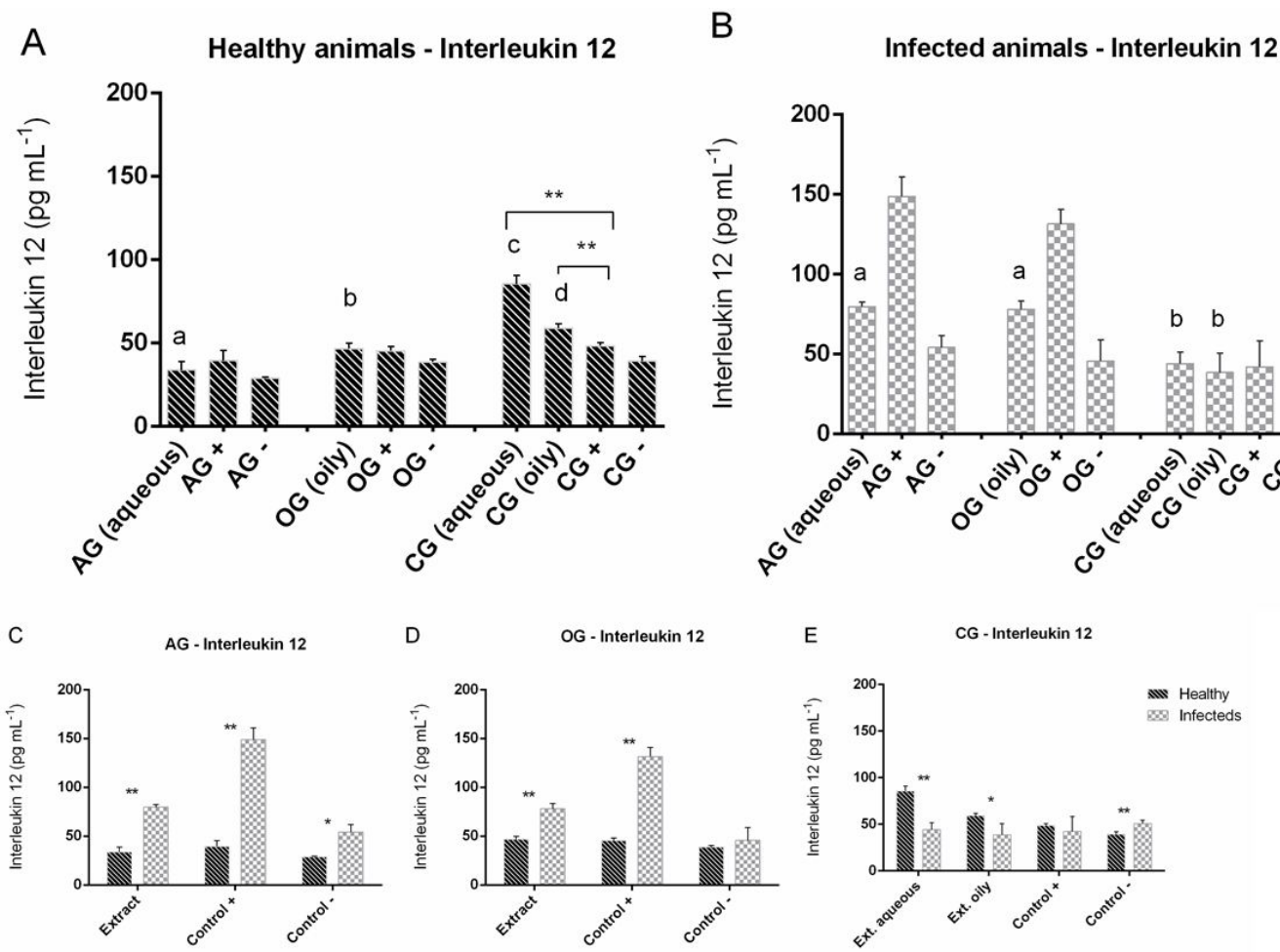

Figure 4. The IL-12 concentration released in PECs culture treated with 3\% sodium thioglycolate of Swiss mice healthy and infected with $S$. schenckii fungus on the $10^{\text {th }}$ day after infection. AG (group that received aqueous extract), OG (group that received oily extract) and CG (group that received PBS) by gavage. The animals macrophages were cultured in aqueous extract ( $1 \mathrm{mg} \mathrm{mL}^{-1}$ ), oily extract ( $1 \mathrm{mg} \mathrm{mL}^{-1}$ ), LPS (Control +) and only RPMI-1640-C (Control -). Same letters does not show significantly difference. Different letters show significantly difference (ANOVA - Tukey post-test $(\mathrm{p}<0.05)$ ). Comparison between extract stimulus in A, B. Comparison between healthy and infected in C, D and E $\left(* \mathrm{p}<0.05 ; *^{*} \mathrm{p}<0.01\right)$.

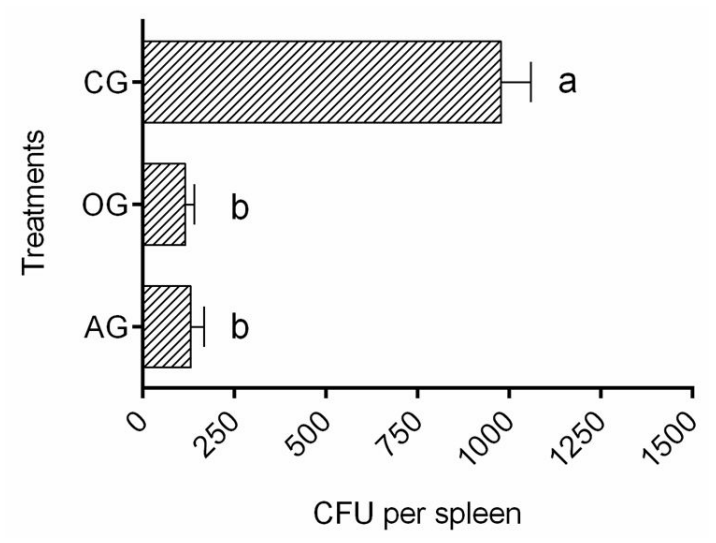

Figure 5. Determination of fungal load (CFU). AG (group that received aqueous extract), OG (group that received oily extract) and CG (group that received PBS) by gavage. The animals of groups AG, OG and CG were inoculated by intraperitoneal access with $10^{6} \mathrm{~S}$. schenckii yeast in PBS. On the $10^{\text {th }}$ day post-inoculation, the mice were euthanized and their spleens removed to determine the systemic fungal load. Results obtained are as mean \pm standard deviation of four animals per treatment in two independent experiments. Different letters represent significant differences (ANOVA Tukey post-test $(\mathrm{p}<0.01))$. against in vivo fungus. In addition, the aqueous and oily extracts showed to be capable of inhibiting $S$. schenckii growth, respectively, at doses of 0.62 and $2.5 \mathrm{mg} \mathrm{mL}^{-1}$, demonstrating effectiveness against in vitro fungus.

The most ability in infection control may be justified by the fact that the destruction of invaders by macrophages is significantly increased with the garlic extract elements, which it increases the number of peritoneal macrophages, their action, and expression of receptors in the membranes (Ghazanfari et al., 2006). The treatment with garlic then may be indicated as a complementary and alternative way of therapy, thereby decreasing the dose of medication used.

The Immunity against fungus shows up the importance of Th1 pathway, where there is a release of cytokines such as IFN- $\gamma$, IL-1 and IL-12. On the other hand, the Th2 pathway that releases stimulating citokines of antibody production (IL-4, IL-5-10 and IL-10) shows limited value in the host defense against these agents (Giraldo and Witkin, 1998). In the immune response against sporotrichosis, macrophages when activated in culture with fungal cell wall components produce proinflammatory cytokines such as IL-1, which stimulate phagocytic response (Carlos et al., 2009) and release intermediate nitrogen and oxygen compounds with fungicide function (Carlos et al., 2003). The ability 
of active macrophages release NO is very important in host defense, as it allows the attack to different types of pathogens (Janeway et al., 2000).

The same can be seen in this work where animals consuming garlic have showed higher levels of pro-inflammatory interleukins (IL-1 $\beta$ and IL-12) when infected, however, when in a healthy state, the anti-inflammatory cytokine (IL-10) suffered an increase in the production. Considering that excessive inflammation is a critical factor in many human diseases including cancer, obesity, cardiovascular diseases, neurodegenerative and intestinal diseases, type I diabetes, and even in aging (Santangelo et al., 2007), to know and to use food capable of decreasing the inflammatory response, such as garlic, it turns to be very important, allowing to modulate the $\mathrm{NO}$ and cytokines secretion by feeding, giving a natural approach to treating these diseases.

Also, according to the results of this study, garlic may be used to fight pain, since its consumption decreases the production of IL- $1 \beta$ in healthy animals. The IL- $1 \beta$ leads to systemic inflammation through the activation of cyclooxygenase-2, with PGE2 formation in the anterior hypothalamus, having an important role in the development of pain (Oliveira et al., 2011). Fabian et al. (2013) showed that treatment with allicin in culture of 3T3-L1 adipocytes, was able to restrain the inflammatory induction by LPS. Considering the fact that in our study garlic also had a positive modulatory action on the immune system induced by oral administration, perhaps garlic may be a functional food to be highly recommended in the treatment of contemporary chronic diseases, with inflammatory condition, as with obesity.

In short, garlic extract shows potential antifungal against S. schenckii. and oral administration of garlic extracts influences the release of cytokines by macrophages, regular consumption shows anti-inflammatory effect, while the acute use might bring forth an inflammatory response. Animals that consumed garlic responded more effectively to fight the infection.

However, more studies are needed to fully understand the garlic action to fight infections, and thereby elucidate alternatives to combat fungal infections and possible treatments less toxic to the host.

\section{References}

ABBAS, K.A., ANDREW, H.H., LICHTMAN, A.H.H. and PILLAI, S., 2012. Imunologia celular e molecular. Rio de Janeiro: Elsevier Brasil. 560 p.

ABREU MATOS, F.J., 2000. Plantas medicinais: guia de seleção e emprego de plantas usadas em fitoterapia no nordeste do Brasil: doenças evitáveis. Fortaleza: Imprensa Universitária-UFC. 346 p.

ALEGRANCI, P., 2013. Análise dos macrófagos M1 e M2 durante a infecção por Sporothrix schenckii em modelo murino. Araraquara: Universidade Estadual Paulista, 97 p. PhD Thesis.

AMAGASE, H., PETESCH, B.L., MATSUURA, H., KASUGA, S. and ITAKURA, Y., 2001. Intake of garlic and its bioactive components. The Journal of Nutrition, vol. 131, no. 3s, pp. 955S-962S. PMid:11238796.
ANKRI, S. and MIRELMAN, D., 1999. Antimicrobial properties of allicin from garlic. Microbes and Infection, vol. 1, no. 2, pp. 125-129. PMid:10594976. http://dx.doi.org/10.1016/S12864579(99)80003-3.

BARROS, M.B.L., SCHUBACH, T.P., COLL, J.O., GREMIÃO, I.D., WANKE, B. and SCHUBACH, A., 2010. Esporotricose: a evolução e os desafios de uma epidemia. Revista Panamericana de Salud Pública, vol. 27, no. 6, pp. 455-460. PMid:20721446.

BAYAN, L., KOULIVAND, P.H. and GORJI, A., 2014. Garlic: a review of potential therapeutic effects. Avicenna Journal of Phytomedicine, vol. 4, no. 1, pp. 1-14. PMid:25050296.

CARLOS, I.Z., SASSÁ, M.F., SGARBI, D.B., PLACERES, M.C. and MAIA, D.C., 2009. Current research on the immune response to experimental sporotrichosis. Mycopathologia, vol. 168, no. 1, pp. 1-10. PMid:19241140. http://dx.doi.org/10.1007/ s11046-009-9190-z.

CARLOS, I.Z., SGARBI, D.B., SANTOS, G.C. and PLACERES, M.C., 2003. Sporothrix schenckii lipid inhibits macrophage phagocytosis: involvement of nitric oxide and tumour necrosis factor-alpha. Scandinavian Journal of Immunology, vol. 57, no. 3, pp. 214-220. PMid:12641649. http://dx.doi.org/10.1046/j.13653083.2003.01175.x.

CERQUEIRA, N.F. and YOSHIDA, W.B., 2002. Óxido nítrico: revisão. Acta Cirurgica Brasileira, vol. 17, no. 6, pp. 417-423.

COELHO-CASTELO, A.A.M., TROMBONE, A.P.F., ROCHA, C.D. and LORENZI, J.C.C., 2009. Immune response to infectious diseases. Medicina, vol. 42, no. 2, pp. 127-142.

CORRÊA-CAMACHO, C.R., DIAS-MELICIO, L.A. and SOARES, A.M.V.C., 2007. Atherosclerosis, an inflammatory response. Arq Ciênc Saúde, vol. 14, no. 1, pp. 41-48.

FABIÁN, S.Q., SAHAGÚN, D.O., CARRERA, M.V. and ROA, R.L., 2013. Alliin, a garlic (Allium sativum) compound, prevents LPS-induced inflammation in 3T3-L1 adipocytes. Mediators of Inflammation, vol. 2013, pp. 381815. PMid:24453416.

FERREIRA, L.S., GONÇALVES, A.C., PORTUONDO, D.L., MAIA, D.C., PLACERES, M.C., BATISTA-DUHARTE, A. and CARLOS, I.Z., 2015. Optimal clearance of Sporothrix schenckii requires an intact $\mathrm{Th} 17$ response in a mouse model of systemic infection. Immunobiology, vol. 220, no. 8, pp. S0171-S2985. PMid:25776919. http://dx.doi.org/10.1016/j.imbio.2015.02.009.

FISCHER, G., HÜBNER, S.O., VARGAS, G.D. and VIDOR, T., 2008. Imunomodulação pela própolis. Arquivos do Instituto Biologico, vol. 75, no. 2, pp. 247-253.

GARCÍA GÓMEZ, L.J. and SÁNCHEZ-MUNIZ, F.J., 2000. Revisión: efectos cardiovasculares del ajo (Allium sativum). $A L A N$, vol. 50, no. 3, pp. 219-229.

GHAZANFARI, T.Z., HASSAN, Z.M. and KHAMESIPOUR, A., 2006. Enhancement of peritoneal macrophage phagocytic activity against Leishmania major by garlic (Allium Sativum) treatment. Journal of Ethnopharmacology, vol. 103, no. 3, pp. 333-337. PMid:16213117. http://dx.doi.org/10.1016/j.jep.2005.08.026.

GIRALDO, P.C. and WITKIN, S.S., 1998. Vaginal candidiasis: an incomprehensible challege. Jornal Brasileiro de Doenças Sexualmente Transmissiveis, vol. 10, no. 5, pp. 31-36.

GREEN, L.C., WAGNER, D.A., GLOGOWSKI, J., SKIPPER, P.L., WISHNOK, J.S. and TANNENBAUM, S.R., 1982. Analysis of nitrate, nitrite, and $[15 \mathrm{~N}]$ nitrate in biological fluids. Analytical 
Biochemistry, vol. 126, no. 1, pp. 131-138. PMid:7181105. http:// dx.doi.org/10.1016/0003-2697(82)90118-X.

HARRIS, J.C., COTTRELL, S.L., PLUMMER, S. and LLOYD, D., 2001. Antimicrobial properties of Allium sativum (garlic). Applied Microbiology and Biotechnology, vol. 57, no. 3, pp. 282286. PMid:11759674. http://dx.doi.org/10.1007/s002530100722.

HOLUB, B.J., ARNOTT, K., DAVIS, J.P., NAGPURKAR, A. and PESCHELL, J., 2002. Organosulfur compounds from garlic. In: J. SHI, G. MAZZA and M.L. MAGUER, eds. Functional foods. Washington: CRC, pp. 213-231. vol. 2.

JANEWAY, C.A., TRAVERS, P., WALPORT, M. and DONALD CAPRA, J., . 2000 Imunobiologia: o sistema imune na saúde e na doença. 4th ed. Porto Alegre: Artes Médicas Sul.

KLIMP, A.H., DE VRIES, E.G., SCHERPHOF, G.L. and DAEMEN, T., 2002. A potential role of macrophage activation in the treatment of cancer. Critical Reviews in Oncology/Hematology, vol. 44, no. 2, pp. 143-161. PMid:12413632. http://dx.doi.org/10.1016/ S1040-8428(01)00203-7.

MARQUES, S.A., FRANCO, S.R.V.S., CAMARGO, R.P., DIAS, L.D.F., HADDAD JÚNIOR, V. and FABRIS, V.E., 1993. Esporotricose do gato doméstico (Felis catus): transmissão humana. Revista do Instituto de Medicina Tropical de Sao Paulo, vol. 35, no. 4, pp. 327-330. PMid:8115791. http://dx.doi.org/10.1590/ S0036-46651993000400004.
MILNER, J.A. and DONATO, F.R., 2010. Bioactive compounds and cancer. New York: Springer Science+Business Media. 896 p.

MORIHARA, N., SUMIOKA, I., MORIGUCHI, T., UDA, N. and KYO, E., 2002. Aged garlic extract enhances production of nitric oxide. Life Sciences, vol. 71, no. 5, pp. 509-517. PMid:12052435. http://dx.doi.org/10.1016/S0024-3205(02)01706-X.

OLIVEIRA, C.M.B., TSA, R.K.S., ISSY, A.M., GEROLA, L.R. and SALOMÃO, R., 2011. Citocinas e dor. Revista Brasileira de Anestesiologia, vol. 6, no. 2, pp. 255-265.

PARHAM, P., 2011. O sistema imune. 3rd ed. Porto Alegre: ArtMed. 608 p.

RANDLE, W.M. and LANCASTER, J.E., 2002. Sulphur compounds in alliums in relation to flavour quality. In: H. D. RABINOWITCH and L. CURRAH, eds. Allium crop science: recent advances. CAB International, pp. 329-356.

SANTANGELO, C., VARI, R., SCAZZOCCHIO, B., DI BENEDETTO, R., FILESI, C. and MASELLA, R., 2007. Polyphenols, intracellular signalling and inflammation. Annali dell'Istituto Superiore di Sanità., vol. 43, no. 4, pp. 394-405. PMid:18209273.

TREVOR, A.J., MASTERS, S.B. and BERTRAM, K.G., 2014. Farmacologia básica \& clínica. 12th ed. Porto Alegre: AMGH. 